\title{
HOLOCENE HISTORY OF THE ENVIRONMENT AND DEVELOPMENT OF BOGS ON THE EASTERN SLOPE OF THE POLAR AND PRE-POLAR URALS (RUSSIA)
}

\author{
Panova N.K. ${ }^{1}$, Antipina T.G. ${ }^{1}$, Jankovska.$^{2}$ \\ ${ }^{1}$ Botanical Garden, RAS (Ural Branch), Ekaterinburg \\ ${ }^{2}$ Institute for Botany, Academy of Science, Check Republic, Brno
}

natapanova@mail.ru

\begin{abstract}
Deposits of permafrost peat bogs, which have been opened by natural outcrops of rivers and lakes have been investigated in forest-tundra and north taiga zones of eastern slope of the Polar and Pre-Polar Ural Mountains. Pollen and botanical analysis of peat and radiocarbon dating of deposits were used as research methods. Fluctuations of vegetation and ecological conditions were revealed in Holocene from Preboreal till Subboreal periods. The Holocene growth of heat level was shown to be traced by spatial and temporal dynamics of the tree line to northwards. In the warmest Atlantic period taiga forests with predominance of spruce were spreaded on the whole territory. Intensive peat formation have been occurred from 9000 till 4000 years ago.
\end{abstract}

Key words: Holocene, peat bogs, pollen, spores, vegetation, climate changes.

\section{INTRODUCTION}

Research on the Holocene nature dynamics becomes extremely important for understanding the process of modern global warming. Disclosure of relations between nature vegetation communities as dependant upon climate changes in the past is to provide the basis to predict tendencies of their development in the nearest future. The Subarctic regions of northern Eurasia seem to present a key for revealing both regional and global processes in nature areas affected by Atlantic air masses.

It is a known fact that climatic changes of the Holocene time showed the most striking pattern in the Subarctic regions [Grichuk, 1969; Khotinsky, Savina, 1985; Velichko, 1989; 1991; Velichko, Klimanov, 1990; etc.]. Thus, during the Holocene climatic optimum of the Atlanticum, the temperatures of both summer and winter intervals in the North Hemisphere showed the most increment values in high-latitude areas $\left(80-70^{\circ} \mathrm{N}\right)$. A. Velichko [1991, p. 13] came to conclude that general increase of the period thermic level was also due to that marked in high-latitude regions.

Dendroclimatic studies held in the regions of Ural and Siberian Subarctic revealed that range of summer temperatures' variation within and between centuries showed neither significant shifting during the last 1500 years; climatic changes in this region are still influenced by natural factors and but slightly affected by human activities [Vaganov et al., 1996; 1998].

Studies for paleovegetation on bogs in Pre-Ural regions of northern West Siberia started in the first decades of the XX century [Suckachev, 1922; Katz, Katz, 1946; 1948, etc.] resulted to conclude of significant northward spread of forest communities into the zone now occupied by forest-tundra evidencing of significant climatic changes of the post-glacial time.

In the Polar Urals, pollen sequences from peat-bog and lake sediments supplied with 14-C dating were previously examined in northern and southern parts of the mountain-valley tundra zone [Surova, 1967; Surova, Troistky, 1971; Surova et al., 1975]. The authors followed the Holocene climate and vegetation changes from the early Dryas to Sub-Atlanticum, concluding of forest vegetation (mainly Picea) spread into the tundra zone along rivers, during the Holocene climatic optimum forests of the Ural western and eastern slopes were marked to contact in river valleys.

For the region of the Pre-Polar Urals, there is a single publication on the pollen analysis of two buried peat-fields at the Manya-river referred by the author to the Holocene interval [Fedorova, 1951] but lacking the 14C-dates. Pollen spectra of these peat-bog deposits showed dominance of Picea and Pinus grains and up to 3\% broad-leaved pollen grains (Ulmus, Tilia, Quercus, Corylus), leading the author to report of growing then forests of spruce and spruce with Siberian pine thus indicating to the climate more mild as compared to that of present time.

The main goal of our study was to reconstruct features of the Holocene climate, vegetation and bog formation dynamics in previously not examined remote areas of the Polar and Pre-Polar Urals. 


\section{STUDY AREA}

The region of our study is situated on the central part of the Polar Urals (fig.1, A), in the Sob-river basin (a left tributary of the Ob-river), in the forest-tundra zone, at the timberline, where a long-term dendroclimatic observations have been performed [Shiyatov, 1986; 2003; Shiyatov, Mazepa, 2002, etc.]. The study site was located in the Pre-Polar Urals (fig.1, B), in the basin of the Lyapin-river (tributary of the river named Severnaya Sos'va), within the zone of north-taiga forests. The average altitude made about 100-200 m above the sea level.

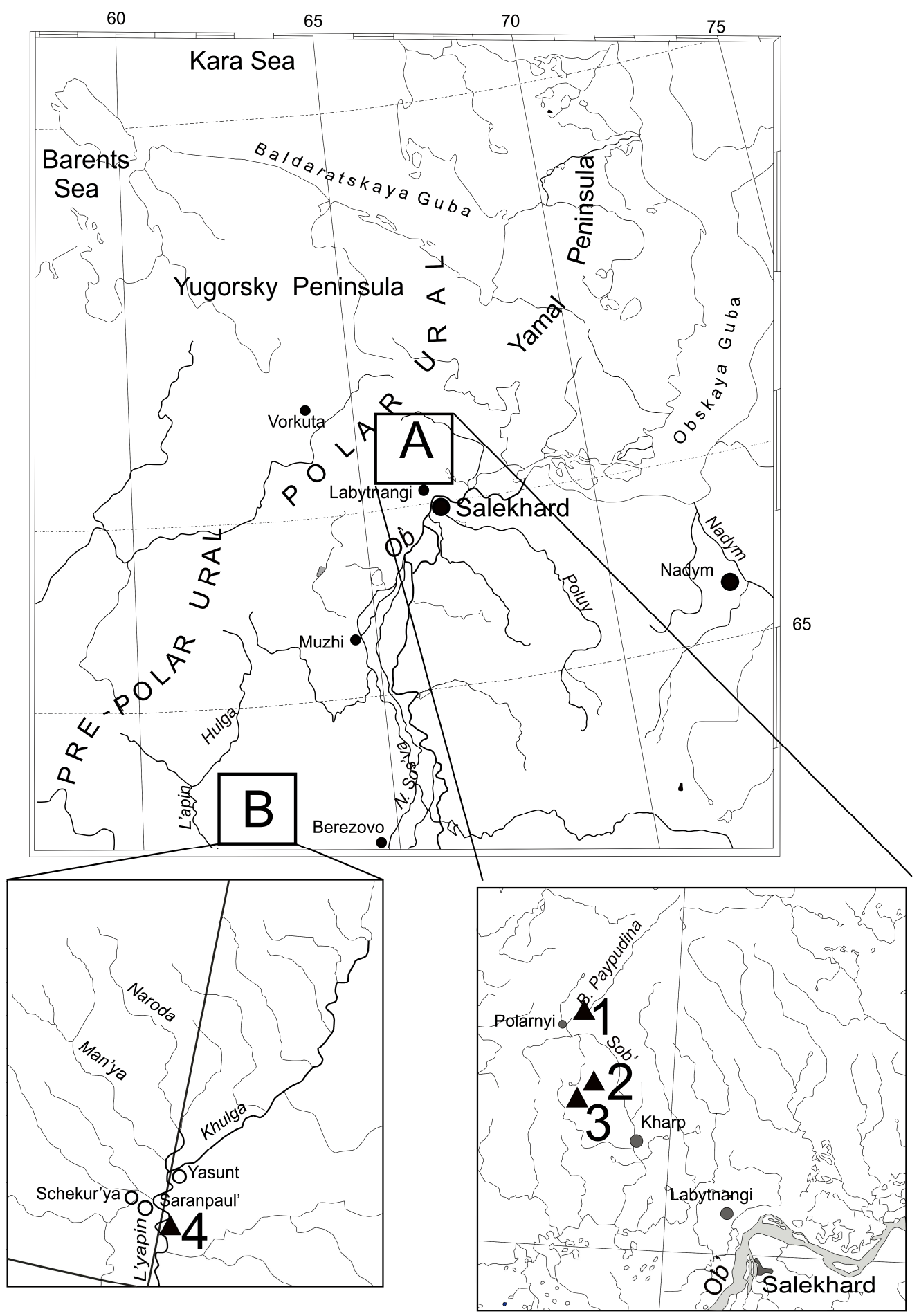

Fig. 1. Map showing the location of the studied site: A - on the Polar Urals, B - on the Pre-Polar Urals. $1-4-$ the sections: 1 - the palsa Chernaya Gorka; 2 - peat bog at the Pereval'noe Lake; 3 - peat bog at the Cherny Ruchey; 4 - peat bog in the bank Lyapin river.

Puc. 1. Карта-схема местонахождения изученных разрезов: А - на Полярном Урале; В - на Приполярном Урале. 1-4 - разрезы: 1 - Черная горка; 2 - у оз. Перевального; 3 - у Черного ручья; 4 - на реке Ляпин. 
Climate of the region of the Polar and Pre-Polar Urals is influenced by the high-latitude radiation regime, intensive cyclonic activity, proximity of the Arctic Ocean, significant relief partition and meridian stretch of ridges [Shvareva, 1962]. Modern climate is described as continental, of the Subarctic-type, with durable cold winter and short cool summer. January average temperatures make from $-19{ }^{\circ} \mathrm{C}$ to $-24{ }^{\circ} \mathrm{C}$; those in July measure $+12-14{ }^{\circ} \mathrm{C}$, in the Pre-Polar Urals up to $+16{ }^{\circ} \mathrm{C}$. Vegetation period (air temperatures over $+10{ }^{\circ} \mathrm{C}$ ) in the Polar Urals forest-tundra areas does not exceed 60 days, making about 80 days at the Pre-Polar Urals eastern slope. Average precipitation value is about $500-700 \mathrm{~mm}$ in mountain forest-tundra areas and not over $450 \mathrm{~mm} /$ per year in the mountain-taiga belt in the Trans-Urals; with maximum precipitation level in summer time. The snow cover in mountains is established in September terminal, staying till June; in the Pre-Polar Urals the snow time begins in mid-October and finished in May. In the Trans-Urals snow cover is about $70 \mathrm{~cm}$ thick; in mountains snow sheet is thicker but not uniform in different areas due to relief features and wind directions. In wide valleys and near to the peaks winds are strong and constant, whereas but fair winds are marked in many closed areas at the eastern slope. Winter winds are mainly south-west, those in summer time come from north and east. An important limiting factor for vegetation is permafrost, during short summer time the soil thaw layer makes no more than $20-30 \mathrm{~cm}$.

The vegetation is the forest-tundra with larch, spruce and birch in the Polar Ural. Open forests were dominated by Larix sibirica, sometimes added with Picea obovata and Betula tortuosa. Open areas are occupied by tundra communities. Bush storey reveals dominance of dwarf birch (Betula nana), presence of different willow species (Salix lanata, S. lapponum, S. phylicifolia, S. reticulata, S. glauca, etc.), alder (Alnus fruticosa). Herbal communities include Ledum palustre, Empetrum hermaphroditum, Arctous alpina, Arctostaphylos uvaursi, Andromeda polifolia, Vaccinium uliginosum, V.vitis-idaea); in damp areas there are marked Rubus chamaemorus, Eriophorum vaginatum), sedges (Carex globularis, C. hyperborea), Menyanthes trifoliata, Parnassia palustris, other mesophilic herbs (Rubus arcticus, Sanguisorba polygama, Polygonum bistorta, P. viviparum, Veratrum lobelianum, Valeriana capitata, Pedicularis oederi, Saxifraga hirculus, Cardamine pratensis, etc.), and horsetails (Equisetum sylvaticum, etc.); Dryas octopetala, Dianthus repens, D. superbus, Silene acaulis, Minuartia arctica, Saxifraga caespitosa, Saussurea alpina are met on dryer slopes. The soil cover is composed of dominating green mosses (Aulacomnium turgidum, Chrysohypnum stellatum, Hylocomium splendens, etc.) and lichen spots (Alectoria, Cladonia alpestris, C. sylvatica, C. rangiferina, Cetraria islandica, C. nivalis, C. cucullata, C. delisei, Dactylina arctica, etc.).

In foot-hills of the eastern slope there grow open forests of spruce-and-larch and of spruce with birch, in some places elevating by valleys up to $150-160 \mathrm{~m}$ high (over the sea level). Practically pure larch forests occupy the pre-goltzy belt. The upper borderline of forest vegetation lies at about 200-250 m a.s.l., rare larch groves are registered up to $300 \mathrm{~m}$.

In the Pre-Polar are forests of spruce (Picea obovata) and Siberian pine (Pinus sibirica), added with birch (Betula pubescens), in the foothills - with Common pine (Pinus sylvestris). Forests in the area are light, coppice, often bogged, with ground waters near to the surface. The soil cover includes green and bog mosses; low shrub storey is composed of Betula nana, Ledum palustre, Vaccinium uliginosum, V.vitis- idaea, etc. Forests alternate with frozen bogs.

Objects of the study were frozen peat-bogs elevated over the water surface as hummocks of different height, which are naturally exposed by erosion of the banks of small and big-sized lakes, and of rivers and streams. Peat layer thickness was not more than $2 \mathrm{~m}$; peat was underlain by lake fine-grain organic and mineral sediments or fine-grained sandy deposits (in river and stream banks). Three peat sections were examined in the Polar Urals.

Peat hummock "Chernaya Gorka" $\left(67^{\circ} 05^{\prime} \mathrm{N} ; 6^{\circ} 21^{\prime} \mathrm{E}\right.$; $170 \mathrm{~m}$ a.s.l.) is situated about $10 \mathrm{~km}$ eastward from the Europe-Asia boundary, $2 \mathrm{~km}$ northward from the settlement Polyarny, in the flood-plain of the Sob'river left tributary, river Bolshaya Paipudyna, in some $100 \mathrm{~m}$ from the river bank. The site is a typical palsa, c $20 \mathrm{~m}$ in diameter and more than $5 \mathrm{~m}$ high at the highest point. The palsa is in a phase of degradation and traces of erosion by wind, water and cryoturbation are notable. The southern side is gradually being destroyed due to thawing within the frozen core, and a small lake $($ c. $20 \times 15 \mathrm{~m})$, roughly similar in size to the palsa, has been formed on the southern side. In riverside vegetation of the lake, Eriophorum russeolum and peat mosses showed dominance.

Peat deposit at the Pereval'ny Lake $\left(66^{\circ} 51^{\prime} \mathrm{N} ; 65^{\circ} 41^{\prime} \mathrm{E}\right.$; $280 \mathrm{~m}$ a.s.1.) is situated in a depression at the south-eastern spur of the Ray-Iz massive, about $30 \mathrm{~km}$ south-eastward from the previous site. Flat-hillock-type peat-bog is adjacent to the lake east bank; peat deposits form an outcrop $190 \mathrm{~cm}$ thick, with lower layers ca. $1 \mathrm{~m}$ over the lake water surface.

The peat-bog at the Cherny Ruchey lies about $1 \mathrm{~km}$ south-westward from the Pereval'ny Lake, within the same depression area, ca. $280 \mathrm{~m}$ a.s.l. Distinct from these two sites, the peat-bog at the Cherny Ruchey was cut 
by the running water, and thus in July (when samples were collected) the section was not frozen. The sediments tested were $120 \mathrm{~cm}$ deep. The lower strongly mineralized strata (down to $140 \mathrm{~cm}$ ) were under water and were not sampled for pollen analysis.

In the Pre-Polar Urals, peat-bog at the Lyapin-river was examined, just near the Kulem'ya-river issue $\left(64^{\circ} 13^{\prime} \mathrm{N} ; 61^{\circ} 04^{\prime} \mathrm{E}\right)$. Peat deposit is elevated over the water surface for about $0.5 \mathrm{~m}$; it was $1.8 \mathrm{~m}$ thick, underlain by sand with humus layer.

Two peat-bog sites in the Polar Urals had been examined and published previously: that at the Pereval'ny lake and the second one named Chernaya Gorka [Panova et al., 2003; Jankovska et al., 2006].

Here we present more detail the results of examination of a small flat peat hummock found at the Cherny Ruchey and another one exposed in the floodplain of the Lyapin-river.

\section{METHODS}

Samples were collected from outcrops during summer field season, as continuous 5-cm columns packed in plastic; samples were treated and examined in winter-time, in the lab. The main methods were botanical and pollen analyses of peat cores dated by 14-C.

Samples were treated by alkaline method after Post and acetolysis [Paleopalynology, 1966]. Mineral samples from down layers were enriched by separation method after V. Grichuk using Cd heavy liquid [Grichuk, Zaklinskaya, 1948].

Pollen diagrams were made by program TILIA and TILIA GRAPH [Grimm, 1992]. Percentages of the taxa for the diagrams were calculated as related to the summed amounts of trees and shrubs pollen regarded for $100 \%$.

Ages of the deposits were C-14-dated in Radiocarbon AP - Sum of trees \& shrubs pollen; NAP - Sum of herbs \& low shrubs pollen in laboratories of different institutes: Institute of Physics, Silesian Technical University in Gliwice (Poland), Institute of Geology (RAS, Siberian Branch, Novosibirsk), Geological Institute (RAS, Moscow), the State University (St-Petersburg). Dates were not calibrated (table 1). All discussed dates are given in the radiocarbon years.

Table 1. Radiocarbon ages (14-C yr BP) from the studied peat bog sections.

Таблица 1. Радиоуглеродный возраст отложений изученных разрезов торфяников.

\begin{tabular}{|c|c|c|c|}
\hline Laboratory No & \multicolumn{2}{|c|}{ The section of the Chernaya Gorka } & 14-C ages yr BP \\
\hline $\mathrm{Gd}-9938$ & $15-20$ & peat & $6020 \pm 200$ \\
\hline $\mathrm{Gd}-10776$ & 150 & peat & $8720 \pm 180$ \\
\hline $\mathrm{Gd}-9947$ & 180 & peat & $8620 \pm 270$ \\
\hline $\mathrm{Gd}-9935$ & 205 & Salix wood & $9230 \pm 280$ \\
\hline \multicolumn{4}{|c|}{ The section at the Pereval'noe Lake } \\
\hline LU-6425 & 150 & peat & $9030 \pm 80$ \\
\hline LU-6424 & 190 & peat & $9270 \pm 110$ \\
\hline \multicolumn{4}{|c|}{ The section at the Cherny Ruchey } \\
\hline SOAN - 3106 & $100-120$ & peat & $5655 \pm 40$ \\
\hline \multicolumn{4}{|c|}{ The section at the Lyapin - river } \\
\hline GIN - 13873 & $20-30$ & peat & $5920 \pm 60$ \\
\hline GIN - 13874 & $142-152$ & peat & $9010 \pm 80$ \\
\hline
\end{tabular}

\section{RESULTS}

Two peat-bog sites in the Polar Urals had been examined and published previously: that one at the Pereval'ny Lake and the second named Chernaya Gorka [Panova et al., 2003; Jankovska et al., 2006]. Spore and pollen diagrams of this peat-bogs (fig. 2,3) revealed similar curves for the main taxa of trees, bushes and some herbs. Four main pollen zones were distinguished:

1. The zone marked by domination of birch pollen, mainly shrub species (Betula nana type), with herbaceous plants represented by pollen of Poaceae, Cyperaceae, Artemisia, Chenopodiaceae and some other herbs - in the bottom stratum of organic-and-mineral lake deposits, indicating cold conditions of tundra or forest-tundra.

2. Zone of willow pollen maximum (Salix), further showing high amounts of green mosses (Bryales) and algae registered in the upper part of the lake sediments, marking warmer conditions, spread of bushes and overgrowth of the water pool. 


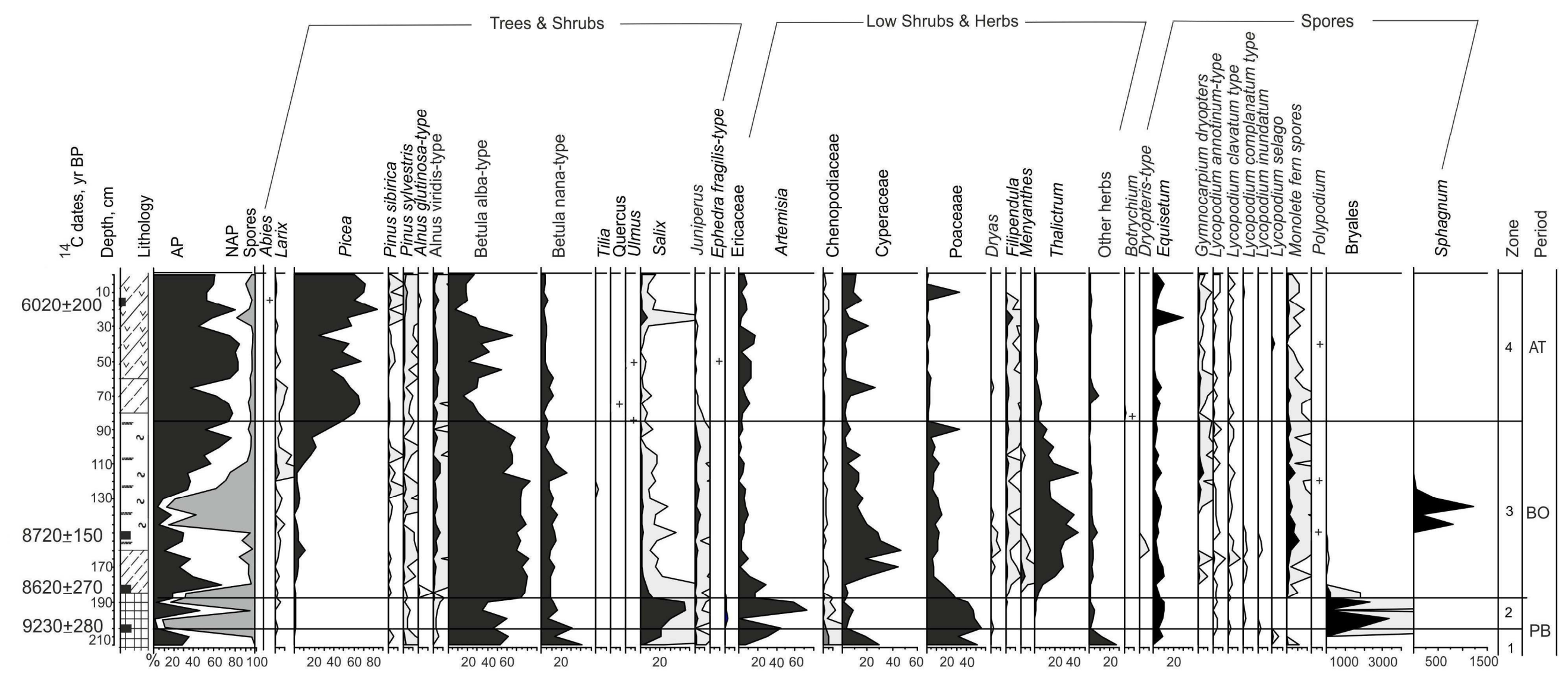

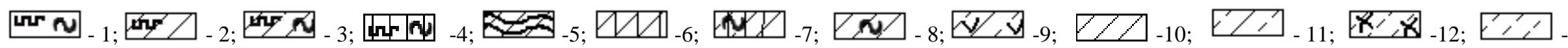
13;

Fig. 2. Pollen and spore diagram of the Chernaya Gorka palsa section. Polar Ural Mts. $\left(67^{\circ} 05^{\prime} \mathrm{N}, 65^{\circ} 21^{\prime}\right.$ E; $170 \mathrm{~m}$ a.s.1.). Pollen analyst V. Jankovska. Puc. 2. Спорово-пыльцевая диаграмма разреза торфяного бугра Черная горка. Полярный Урал. Аналитик В. Янковска. 


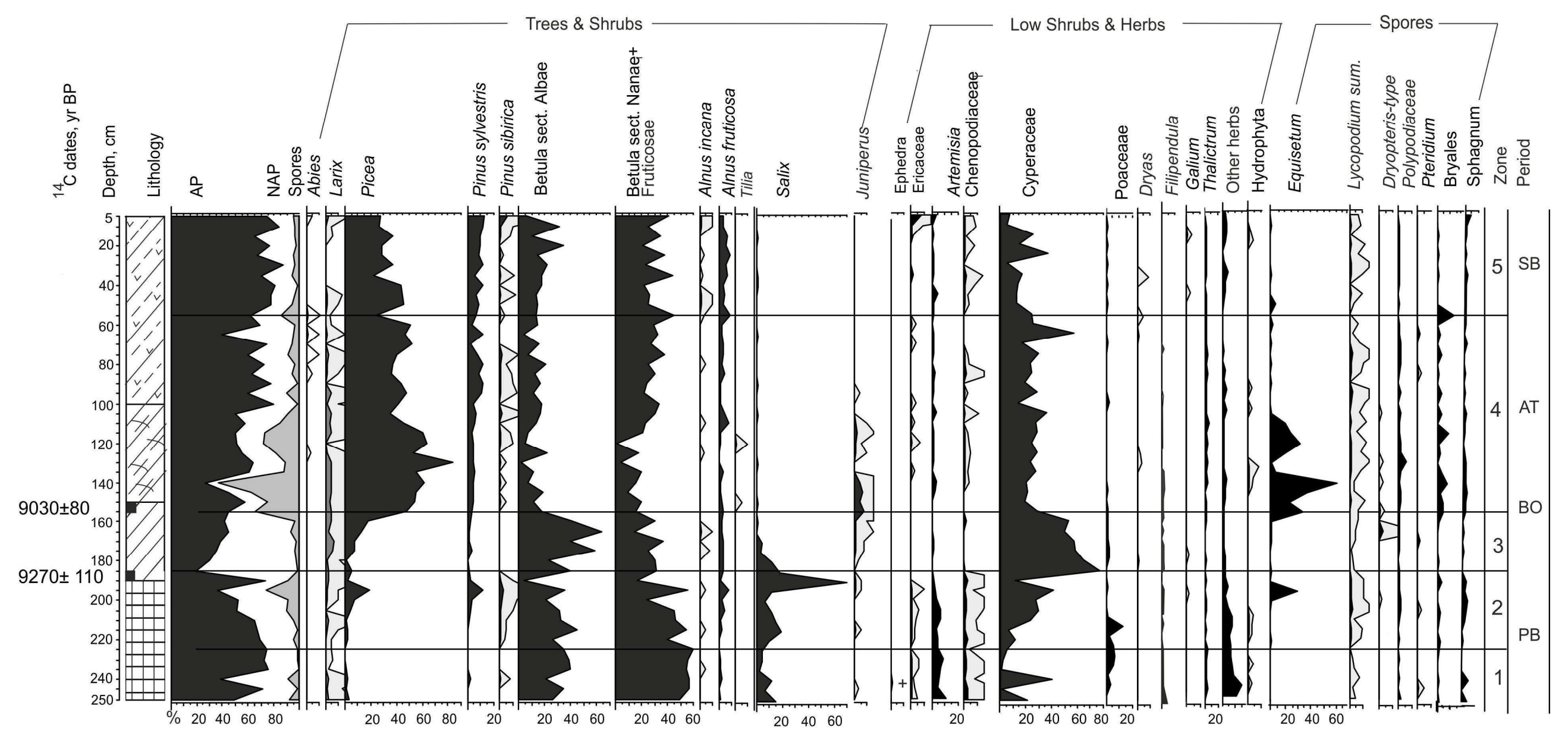

Fig. 3. Pollen and spore diagram of the peat bog section at the Pereval'noe Lake. Polar Ural Mts (66 $51^{\prime}{ }^{\prime} \mathrm{N} ; 65^{\circ} 41^{\prime} \mathrm{E}$; $280 \mathrm{~m}$ a.s.l.). Pollen analyst N.K. Panova. Puc. 3. Спорово-пыльцевая диаграмма разреза торфяника у озера Перевального. Полярный Урал. Аналитик Н.К. Панова. 


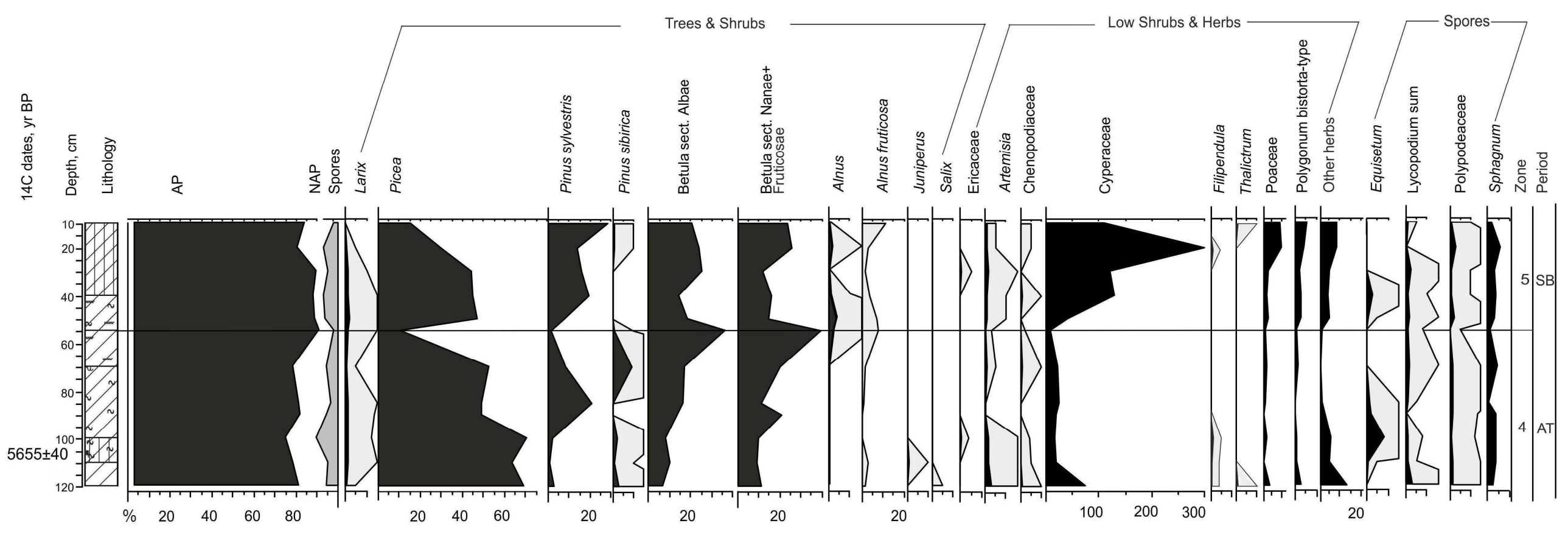

Fig. 4. Pollen and spore diagram of the peat bog section at the Cherny Ruchey. Polar Ural Mts. (66 $51^{\prime}$ N; $65^{\circ} 40^{\prime}$ E; 280 m a.s.1.). Pollen analyst N. Panova. Puc. 4. Спорово-пыльцевая диаграмма разреза торфяника у Черного ручья. Полярный Урал. Аналитик Н.К. Панова.

Conditional sign to figures 2-5

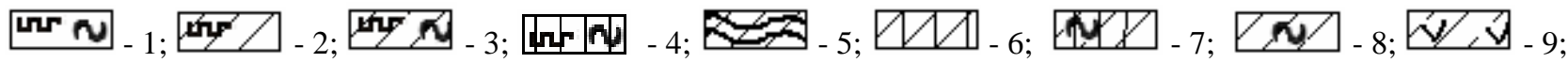
$\angle Z$ - $_{10}$
0
11; 8\% - 12;
-13;
$\because \cdots \cdots$

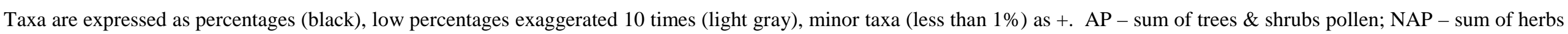
$\&$ low shrubs pollen; Spores - sum of spores.

Sediment types

1 - 5 - mesotrophic peat: 1 - Sphagnum, 2 - Sedge-Sphagnum, 3 - Sedge , 4 - Woody-Sphagnum , 4 - Eriophorum- Sphagnum; 6 - 13: low-mire peat: 6 - Woody-sedge, 7 Woody-sedge-Sphagnum, 8 - Sedge-Sphagnum, 9 - Hypnum-herbs-sedge, 10 - Sedge, 11 - Sedge-Hypnum, 12 - Equisetum- Hypnum, 13 - Hypnum; 14 - Mergel; 15 - Sand. 


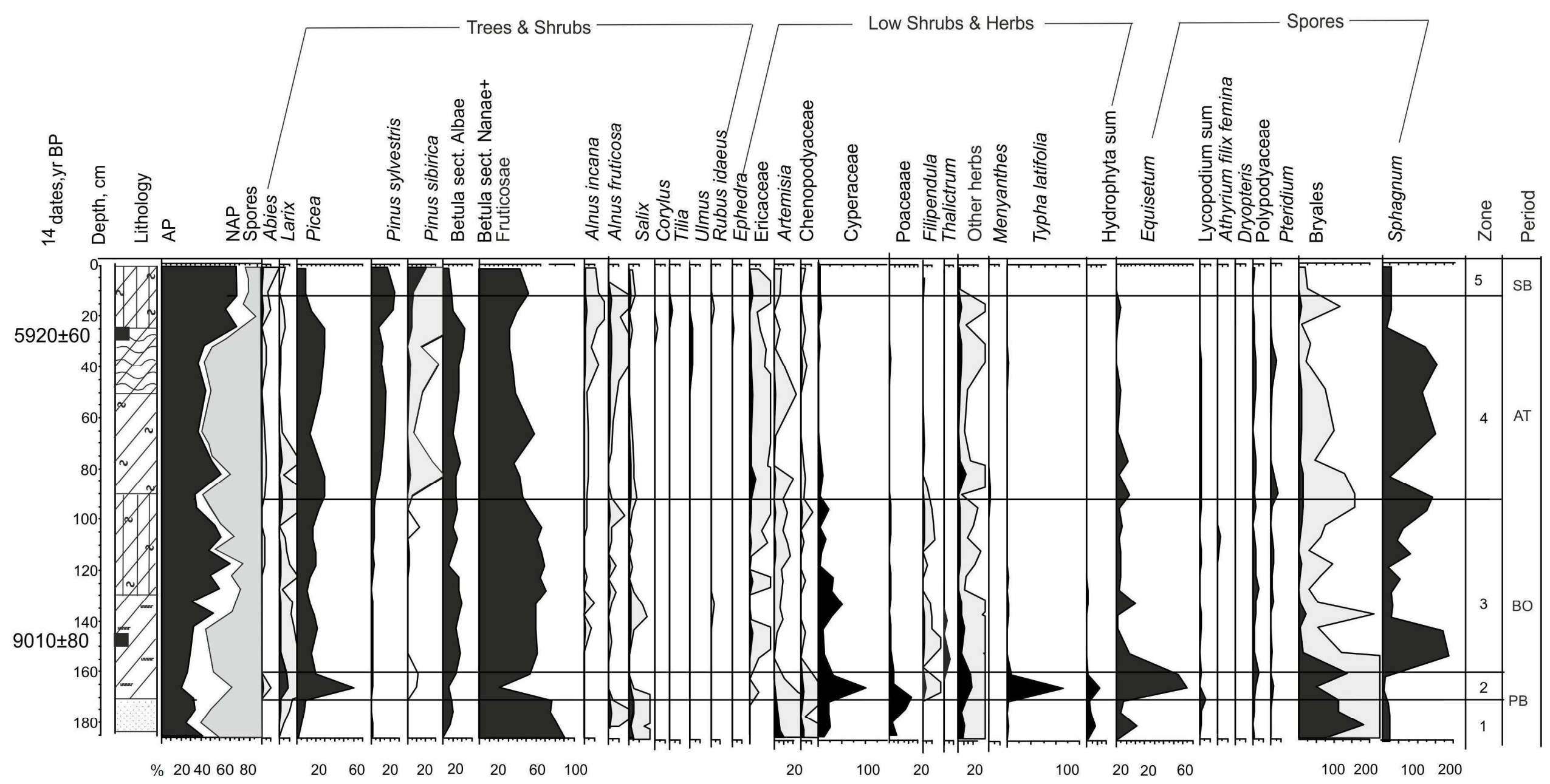

Fig. 5. Pollen and spore diagram of the peat bog section in the Lyapin river. Pre-Polar Ural Mts. (64 ${ }^{\circ} 13^{\prime}$ N; $61^{\circ} 04^{\prime}$ E; about $100 \mathrm{~m}$ a.s.1.). Pollen analyst T. Antipina. Puc. 5. Спорово-пыльцевая диаграмма разреза торфяника на реке Ляпин. Приполярный Урал. Аналитик Т.Г.Антипина. 
3. Zone with prevalence of pollen of birches (Betula sec. Albae) and sedges (Cyperaceae) observed in lower part of peat deposit, reflecting the beginning of paludification and peat formation; apparently open forests of larch and birches were also present in the area.

4. Zone of spruce (Picea) pollen dominance, showing two Picea pollen peaks (the lower and upper ones), separated by an increase of birch pollen in the main peat layers, corresponding to the taiga forests dominated by spruce trees.

5. The zone marked by a decrease of spruce pollen and by higher numbers of birch and shrubs pollen grains (Alnus fruticosa type, Betula nana type) was observed only in peat upper layers at the Pereval'ny Lake, the spectra indicating to the colder climate, spruce retreat and thinning of forest stands.

In the peat section Chernaya Gorka this pollen zone was not found, because the hummock surface was destroyed due to cryogenic processes and eolation.

Dating of the samples revealed that zones 1 and 2 correspond to the Preboreal time, zone 3 - to the Boreal, zone 4 marked the Atlantic, and zone 5 - the Subboreal interval.

The peat-bog at the Cherny Ruchey seemed interesting to us, as it was ever examined for plant macrofossils and C-14 age [Koshkarova et al., 1999]. The dates showed that peat formation also started during the Boreal period: the peat bottom layer (130-140 cm deep) presented the date $8530 \pm 50 \mathrm{yr} \mathrm{BP}$ (SOAN-3028).

The peat sample from the layer 100-120 cm deep was dated at 5655 40 (SOAN-3106). Stratigraphy of the section and our results of pollen analysis are shown on fig. 4. The following pollen zones have been distinguished on the diagram (upward from the bottom):

Zone 4 - of spruce (Picea) dominance $(55-120 \mathrm{~cm}$ deep) - corresponds to pollen zone 4 marked on the diagrams from the Pereval'ny Lake and Chernaya Gorka sites referred to the second half Atlantic period.

Zone $5(5-55 \mathrm{~cm}$ deep) correspond to Subboreal time.

The spectrum from 50-55 $\mathrm{cm}$ deep demonstrated a significant decrease of spruce pollen, whereas numbers of birch and shrub pollen grains (Betula nana type, Alnus fruticosa type) were marked to grow. These features probably mark some short and abrupt climate shifting towards cold and aridity, at about the boundary of the Atlanticum and Subboreal intervals, ca. 4500 years ago.

Upwards, spruce pollen grains numbers increased again. Spectra from the samples $30-50 \mathrm{~cm}$ deep indicate to warmer and more humid conditions of mid-Subboreal time.

In the upper 30-cm peat layer spruce pollen again was marked to decrease, contrary to the growth of pollen numbers of birches, pines, bushes, sedges and grasses, different herbs, horse-tails and peat mosses. The spectra indicate to the vegetation similar to the modern type, that of forest-tundra communities with larch, spruce, and birch trees.

Figure 5 presents stratigraphy of the section and pollen diagram of the peat bog at the Lyapin-river. Two peat samples have been radiocarbon- dated: that from the layer 140-150 cm deep gave $9010 \pm 80$ (GIN-13874), and the age of $5920 \pm 60$ years BP (GIN-13873) corresponded to the layer of $20-30 \mathrm{~cm}$, indicating that peat formation was started during the Preboreal time (before 9000 years ago), finishing in the Subboreal. The following pollen zones may be distinguished (upwards from the bottom):

1. Zone marked for prevalence of shrubs (Betula sec. Nanae + Fruticosae, Salix), herbs (Artemisia, Chenopodiaceae, Poaceae, Cyperaceae), green mosses (Bryales) and algae (genus Pediastrum) in the layer190$170 \mathrm{~cm}$ deep. Spruce and birch pollen grains are rare. The spectra indicate to the habitats of herbaceous tundra with shrubs or the forest-tundra, with a shallow water pool in the vicinity. The sediments were formed probably during the late Dryas / early Preboreal time.

2. Zone of the layer 170-160 $\mathrm{cm}$ deep reveals sharp growth of spruce (Picea) and larch (Larix) pollen, accompanied by decline of the role of birch shrubs, Artemisia, Chenopodiaceae. Such proportions evidence of the climate turning warmer and more humid. Pollen peaks (maxima) of aquatic and waterside plants as Typha, Potamogeton, Alisma, Nuphar, as well as those of sedges (Cyperaceae), different herbs, horse-tails (Equisetum) indicate to starting overgrowth and paludification of the water pool. This pollen zone might be referred to the Preboreal second half.

3. Zone of the layer within $160-100 \mathrm{~cm}$ demonstrated domination of birches and significant pollen numbers of spruce, sedges and peat mosses. This spectra type would reflect communities of open forests with larch, birches and spruce, different herbs and ferns in the cover, and a sedge fen with peat mosses. Sediments corresponding to pollen zone 3 probably had been formed during the Boreal time and the Atlanticum beginning.

4. Zone within 100-20 cm deep is marked for maximum spruce pollen values. Amount of shrub birches' pollen falls; Common pine (Pinus sylvestris) and Siberian pine (Pinus sibirica) pollen have been revealed in noticeable number. The picture corresponds to the vegetation of taiga-type spruce forests with admixture of birches, Common and Siberian pines, rare - with fir (Abies sibirica). Peat mosses (Sphagnum) show prevalence on the bog. The zone corresponds to warm and moderate-humid conditions of the Atlantic second half, which might also be confirmed by the finds of Ulmus and Tilia single grains. 
5. Zone of the upper $20 \mathrm{~cm}$ shows prevailing pollen grains of shrub birches, maximum amount of pine pollen and significantly lower spruce numbers. The pattern should indicate to the colder and more continental climate conditions. The vegetation seems to be similar to the north taiga type: forests of spruce, Common and Siberian pine with admixture birch. This part of peat deposit had been forming probably during the whole postAtlantic time. Peat formation at that interval turned slower and finally stopped at all.

\section{DISCUSSION}

C-14 dates obtained for the site Chernaya Gorka refer the organogenic sediments within the limits of 9800-5500 $\mathrm{C}^{14}$ yrs BP. Peat formation started both in this site and in the Pereval'ny Lake during the Boreal time, about 9000 yrs BP. Peat formation in deposit at the Cherny Ruchey also started during the Boreal period. In the peat bog at the Lyapin-river peat formation was started some earlier, during the Preboreal time (before 9000 years ago).

Peat accumulation was stopped everywhere probably in the Subboreal, due to cold conditions and freezing of peat-bogs, about 3400 years ago. Tree-ring data revealed strong cold in the region at that time [Khantemirov, Shiyatov, 1999]. At that time, the forest border-line in the Yamal peninsula was marked to retreat significantly southwards, and in the Polar Urals taiga forests were replaced by forest-tundra.

Process of peat formation seemed to be the most intensive during the Boreal and Atlantic times. Aging of the observed pollen zones supplied with 14-C dates and present peat depth allow estimation of peat accumulation rates. Thus the peat-bog Chernaya Gorka accumulated ca. $160 \mathrm{~cm}$ of peat during the interval 9000-6000 yrs B.P., the rate making about $0.5 \mathrm{~mm}$ per year. In the peat-bog at the Lyapin-river accumulated ca. $130 \mathrm{~cm}$ of peat during the same interval, the rate making about $0.4 \mathrm{~mm}$ per year.

In the peat-bog at Cherny Ruchey, the deposit about $50 \mathrm{~cm}$ thick had been formed between 5600 and 4500 years ago, that is, a bit over $0.5 \mathrm{~mm}$ per year. During the Post-Atlantic time (about 4500 years long), the peat-bog at Cherny Ruchey accumulated $60 \mathrm{~cm}$ peat deposit, and the site at the Pereval'ny Lake - not more than $30 \mathrm{~cm}$, the corresponding accumulation rates making ca. $0.13 \mathrm{~mm}$ and $0.07 \mathrm{~mm}$ per year.

To compare, the south-taiga peat-bogs in the Middle Urals demonstrated (judging by the peat-layer thickness and 14-C-dates) peat accumulation rates of the Boreal and Atlantic intervals up to $0.5 \mathrm{~mm} / \mathrm{year}$ [Khotinsky, 1977] and $0.8 \mathrm{~mm} /$ year [Panova et al., 2001]. During the whole post-Atlanticum time, deposition of fuscum peat layers in those peat-bogs showed $0.65 \mathrm{~mm}$ per year, whereas layers of wood-cotton-grass-sphagnum of higher density showed the values up to $0.24 \mathrm{~mm}$ per year.

One can see the rates of peat-bog vertical increment to depend upon a series of factors. Yet the main determinative factor is ratio between the processes of vegetation mass production and decomposition, thus being significantly dependent upon climate conditions, namely heat / humidity ratio. The presented data show that in general, higher peat accumulation rates are registered in the Urals south taiga as compared to those in north taiga and forest-tundra regions, especially during the Holocene second half. The data also indicate much warmer climatic conditions of the Holocene first half in northern regions nearly to those in the Urals middle areas. However, increment values marked for the Holocene second half differed significantly in the north and south taiga regions.

Peat increment values registered in West Siberia distinct botanical-geographical zones [Liss, Berezina, 1978, 1980; Boch, Mazing, 1979; Novikov et al., 1999; Liss et al., 2001; etc.] made the authors to conclude that average rates of peat linear increment values turn lower northwards. Throughout the Holocene time, the highest rate values were marked for sub-taiga bog systems ( $1.1 \mathrm{~mm}$ per year). In the sub-zone of north-taiga open forests of West Siberia (Nadym-Pur interfluve area) has been observed the highest rate of peat accumulation (up to 1 $\mathrm{mm} /$ year) during the last 1000 year interval [Liss, Berezina, 1981]. Kuzmin [1999] presented even more impressive values on the same time span of last 1000 years for regions of Russia North-West (from 0.97 to 7.14 mm per year).

In the site at the Cherny Ruchey, our pollen study revealed good correlation to the analysis of plant macrofossils [Koshkarova et al., 1999]. Thus, samples $60-120 \mathrm{~cm}$ deep all evidenced of the vegetation forest type, indicating to the warmer climate of the period. Seeds and other macrofossils presented spruce, larch and birch (sect. Betula) remains in about equal proportions. The highest amount of spruce macrofossils was found at the depths of 120-140 cm. Shrub birches and willows were not found. Pine seeds were marked in the layer 80$100 \mathrm{~cm}$ deep, corresponding to the pine pollen increase in the sample $85 \mathrm{~cm}$ deep. The identified herb remains belonged mainly to bog-growing plants, including those now registered significantly farther southward, as Comarum palustre, Scheuchzeria palustris, several Carex species, Menyanthes trifoliata, as well as Ericaceae low shrubs: Andromeda polifolia, Empetrum nigrum, Chamaedaphne calyculata, Ledum sp.

Sediments 40-60 cm deep missed spruce macrofossils and those of birches sect. Betula, only larch remains were found, accompanied with numerous Betula nana and Salix remains. That is, carpological data also 
evidenced of cooled and probably dryer climate conditions, thinning of forest stands composed mainly of larch trees in this time.

Spectrum of plant macrofossils collected from the sample $25-40 \mathrm{~cm}$ deep (spruce, larch, Common pine, arboreal and shrub forms of birches) also revealed good correlation to the pollen data. It is indicating to forest communities of birches, larch and spruce with admixture of the Common pine. Boreal species of sedges (Carex diandra, C. vesicaria) were found, too. The author [Koshkarova, 1999] regarded this Subboreal interval as a "xerothermic" one. The pollen data do not evidence of dryer conditions during this Subboreal warming interval. On the contrary, the observed dominance of spruce pollen grains, increase of sedges and some mesophilic herbs (Polygonum bistorta type, Saguisorba sp.) would indicate to significant humidity. This is in conformity with the results by L. Nikiforova [1982], who wrote that territories of European north-east adjacent to the Polar Urals during the Subboreal thermic maximum demonstrated the most developed spruce forests with Abies and Pinus sibirica reaching up to the polar circle line.

Sample from the layer 0-25 cm deep contained only macrofossils of larch (no other trees); prevailing seeds of dwarf birches (Betula nana) and willows, fossils of green mosses, Equisetum palustre; cold-tolerant sedges as Carex caespitosa and Ericaceae low shrubs (Chamaedaphne calyculata, Ledum sp.) were marked, the data indicating to cold conditions of larch forest-tundra similar to those of the present time.

Significant cold growth leading to forest degradation and gradual cessation of peat formation took place probably in the Subboreal terminal. N. Khotinsky [1982] and L. Nikiforova [1982] referred the Subboreal thermal maximum to the interval from 4200 till 3200 years ago. Tree-ring data from the Yamal peninsula [Khantemirov, Shiyatov, 1999] marked drastic cold occurrence about 3400 years ago. That is, the upper peat layer of 25-30 cm was formed during the last 3-3.5 thousand years.

Table 2. Holocene dynamics of nature environment in the Polar and Pre-Polar Urals (by pollen data).

Таблица 2. Голоценовая динамика природных условий на Полярном и Приполярном Урале (по палинологическим данным).

\begin{tabular}{|c|c|c|c|c|}
\hline \multirow{2}{*}{$\begin{array}{l}\text { Holocene } \\
\text { intervals }\end{array}$} & \multicolumn{2}{|c|}{ Vegetation } & \multirow[b]{2}{*}{ Mire formation process } & \multirow{2}{*}{$\begin{array}{l}\text { Climate } \\
\text { conditions }\end{array}$} \\
\hline & Polar Urals & Pre-Polar Urals & & \\
\hline $\begin{array}{l}\text { Preboreal } \\
9800-9200 \\
{ }^{14} \mathrm{C} \text { yr BP }\end{array}$ & $\begin{array}{c}\text { Prevalence of herbs } \\
\text { and bushes; } \\
\text { open forests of larch and } \\
\text { birches }\end{array}$ & $\begin{array}{l}\text { Prevalence of herbs } \\
\text { and bushes; } \\
\text { open forests of larch, } \\
\text { spruce and birches }\end{array}$ & $\begin{array}{l}\text { Cold water pools, } \\
\text { overgrowth starting } \\
\text { (algae) }\end{array}$ & Cold \\
\hline $\begin{array}{l}\text { Boreal } \\
9200-8000 \\
{ }^{14} \mathrm{C} \text { yr BP }\end{array}$ & $\begin{array}{l}\text { Thinned forests of larch } \\
\text { and birches, with some } \\
\text { admixture of spruce }\end{array}$ & $\begin{array}{l}\text { Park-type forests of } \\
\text { larch, spruce and } \\
\text { birches }\end{array}$ & $\begin{array}{l}\text { Start of peat formation } \\
\text { (green and peat mosses, } \\
\text { sedges, horse-tails) }\end{array}$ & $\begin{array}{l}\text { Warmer than } \\
\text { modern type }\end{array}$ \\
\hline $\begin{array}{l}\text { Atlanticum } \\
8000-4500 \\
{ }^{14} \mathrm{C} \mathrm{yr} \mathrm{BP}\end{array}$ & $\begin{array}{c}\text { Taiga-type forests of } \\
\text { spruce, with admixture of } \\
\text { birches and larch }\end{array}$ & $\begin{array}{c}\text { Taiga-type forests of } \\
\text { spruce, with admixture of } \\
\text { birches, larch, common } \\
\text { pine, Siberian pine }\end{array}$ & $\begin{array}{c}\text { Most accumulation of peat } \\
\text { (sedges, horse-tails, peat } \\
\text { mosses) }\end{array}$ & $\begin{array}{l}\text { Temperate } \\
\text { warm and } \\
\text { humid }\end{array}$ \\
\hline $\begin{array}{l}\text { Subboreal } \\
{ }^{4500} \\
{ }^{14} \mathrm{C} \text { yr BP }\end{array}$ & $\begin{array}{l}\text { Open woodlands of larch, } \\
\text { birches and spruce }\end{array}$ & $\begin{array}{c}\text { Decrease of spruce, } \\
\text { increase of common and } \\
\text { Siberian pines in the } \\
\text { forests }\end{array}$ & Peat formation turns slower & Arid and cold \\
\hline $\begin{array}{l}\text { Subboreal/ } \\
\text { Subatlantic } \\
\text { After } 3400 \\
{ }^{14} \text { C yr BP }\end{array}$ & $\begin{array}{l}\text { Forest-tundra with } \\
\text { spruce, birches and } \\
\text { larch }\end{array}$ & North taiga & Freezing of peat-bogs & Cold \\
\hline
\end{tabular}

Larch pollen is known for its bad preservation in sediments, thus even small amount of this pollen grains indicate to the fact that the trees actually grew in the region. Macrofossils evidence of the larch presence in the region during the Holocene all interval: in mid-Holocene forests it was registered together. On the contrary, we regard the Common pine pollen in the Polar Urals as an adventitious form. Increase of the pine pollen numbers in the site upper layers might be regarded to result from the expansion of the species range in West Siberia; 
besides, vast open territories in the forest-tundra landscapes provided free transportation of the pine pollen. Thus, our opinion differs from that by V. Koshkarova, who considered her analysis of plant macrofossils to indicate that the pine occupied the Polar Urals region during the Boreal, Atlantic, and Subboreal periods of the Holocene time.

Our results revealed good correlation with the data presented by T. Surova [Surova et al., 1975], both in the obtained pollen diagrams and in interpretation of the Holocene climate and vegetation changes.

As compared to the results presented by R. Fedorova [1957] for some peat-bogs also in the Polar Urals, the latter reported of significantly higher proportions of arboreal pollen grains in the spectra: up to $70 \%$ of spruce grains in the lower maximum, up to $80 \%$ of the common pine and 3\% of broad-leaved pollen (Ulmus, Quercus, Tilia, Corylus) in the mid-period layers. Such distinctions in pollen spectra structures, as well as the fact that peat-bogs in the Man'ya-river terrace were overlapped by 1 meter thick layer of mineral sediments (of sand and loam) with upper modern soil cover, make us to propose of interglacial age of these peat-bogs.

The revealed dynamics of vegetation changes and process of bog development in the Pre-Polar Urals showed the pattern similar to those in the Polar Urals, indicating to the influence of global climatic changes. The main differences concern the earlier start of peat formation and the spreading of spruce. Common pine and Siberian pine were shown to grow in forests of the Pre-Polar Urals beginning from the Atlantic period. Our data show that in Holocene these species of arboreal vegetation did not reach areas of the Polar Urals. These features are due to latitudinal difference of the localities examined; the Holocene expansion of trees was directed northward along the eastern slope of the Ural mountains and upward toward the hill slopes along the river valleys.

\section{CONCLUSION}

The described general tendencies in the development of forest and bog ecosystems and climatic changes of the Holocene time in the regions are presented in the table 2.

In the Subarctic regions of the Polar and Pre-Polar Urals at the beginning of the Holocene, after mountain ice melting, cold shallow oligotrophic water pools had been formed, surrounded by plant communities of herbs and bushes of the tundra-type.

After warming came in the Preboreal and Boreal time, degradation of permafrost lead to development of plots of stagnant flooding, there began overgrowth and paludification of water pools followed by the process of peat formation. In the surrounding areas, willow and alder shrubs increased in number and distribution, later followed by trees: larches, birches, and thereafter by spruce.

Spruce was present in the Pre-Polar Urals in the Preboreal period. About 9000 years ago spruce reached the Polar Urals (region of Pereval'ny Lake) and about 8000 years ago it appeared in the valley of Bolshaya Paypudina river.

In the mid-Holocene time (8000-4500 years ago), the whole region was occupied by the forests dominated with spruce, in the Pre-Polar Urals - with admixture of Common and Siberian pines, probably of the middle-taiga and south-taiga types; process of peat formation developed the most intensively.

The colder climate of the Subboreal time caused thinning of the forest stands, retreat of the spruce, accompanied with wider expansion of Common and Siberian pines in the Pre-Polar Urals. Process of peat formation was slowing down, and later on stopped at all, followed with freezing of the peat-bogs and formation of frozen peat hummocks.

For more detailed reconstructions of the Holocene nature dynamics, further research is needed, using numerous $\mathrm{C}-14$ datings of the samples.

\section{ACKNOWLEDGEMENTS}

Authors are much grateful to S.G. Shiyatov, V.S. Mazepa, R.M. Khantemirov, A. Surkov, Yu.M. Alesenkov, R.R. Semyashkin - for their help in the expedition work. Great thank to G.V. Bykova for the translation of this article into English.

This study was supported by the Biological Diversity Program of the Presidium of the Russian Academy of Sciences, project no. PP-1, and Integration Project of the Ural Branch of RAS - Siberian Branch of RAS, project no. PP-2.

\section{REFERENCES}

Boch M.C., Mazing V.V. 1979. Ecosystems of bogs in USSR. Leningrad: Nauka. 188 pp. (in Russian).

Grichuk V.P. 1969. Reconstruction of some elements of climate in the Northern Hemisphere during the Atlantic period of the Holocene time // Holocene / Neistadt M.I. (ed.). Moscow: Nauka. P. 41-57. (in Russian).

Grichuk V.P., Zaklinskaya E.D. 1948. Analysis of fossil pollen and spores and its application in paleogeography. Moscow: OGIS. 224 pp. (in Russian).

Grimm E.C. 1992. TILIA 1.11 and TILIA GRAPH 1.17. Illinois state museum, Research and Collection center. Springfield. 65 pp. 
Fedorova R.V. 1951. Materials of a paleobotanical investigation of the buried peat-bogs in the Pre-Polar Urals // Izvestiya Vsesoyuznogo Geograficheskogo obshchestva. V. 83. No 6. P. 635-640. (in Russian).

Jankovska V., Andreev A.A., Panova N.K. 2006. Holocene environmental history on the eastern slope of the Polar Ural Mountains, Russia // Boreas. V. 35. P. 650-661. Oslo.

Katz N.Ya., Katz S.V. 1946. History of vegetation on bogs of north Siberia as an indicator of changes in post-glacial landscape // Trudy Instituta geographii AN SSSR. T. 37. P. 331-348. (in Russian).

Katz N.Ya., Katz S.V. 1948. Stratigraphy of peat-bogs in the northern regions near the Ob-river // Trudy Komissii po izucheniyu chetvertichnogo perioda. T. 7. No.1. P.15-54. (in Russian).

Khantemirov R.M., Shiyatov S.G. 1999. Main stages of development of tree vegetation in the Yamal peninsula during the Holocene // Russian Journal of Ecology. No 3. P. 163-169.

Khotinsky N.A. 1977. Holocene in the North Eurasia. Moscow: Nauka. 200 pp. (in Russian).

Khotinsky N.A. 1982. Holocene chronological sequences: discussed problems of the Holocene paleogeography // Razvitiye prirody territorii SSSR v pozdnem Pleistocene i Holocene / Velichko A.A. (ed.)]. Moscow: Nauka. P.154-162. (in Russian).

Khotinsky N.A., Savina S.S. 1985. Paleoclimatic essays of the USSR territory during the Boreal, Atlanticum and Subboreal intervals of the Holocene // Izvestiya AN SSSR. Geographical series. No 4. P.18-34. (in Russian).

Koshkarova V.L., Karpenko L.V., Orlova L.A. 1999. The Holocene dynamics of vegetation and the upper forest limit in the Polar Urals // Russian Journal of Ecology. No 2. P. 121-125.

Kuzmin G.F. 1999. Dynamics of bog-formation process in North-West of Russia and some problems of nature management // Bolota i zabolochennie lesa v svete zadach ustoichivogo prirodopolzovaniya. Materialy konferentsii / Vompersky S.A. and Sirin A.A. (eds.) Moscow: GEOS. P. 72-76. (in Russian).

Liss O.L., Berezina N.A. 1978. Age of bogs and intensity of peat accumulation in central part of West-Siberian plain // Genesis and dynamics of bogs. Issue 2 / Liss O.L. (ed.). Moscow University Press. P. 12-19. (in Russian).

Liss O.L., Berezina N.A. 1981. Bogs of West-Siberian plain. Moscow University Press. 208 pp. (in Russian).

Liss O.L., Abramova L.I., Avetov N.A., Berezina N.A., Inisheva L.I., Kurnishkova T.V., Sluka Z.A., Tolpisheva T.Y., Shvedchikova N.K. 2001. Bog systems of West Siberia and significance of those for nature conservation. Moscow. 584 pp. (in Russian).

Nikiforova L.D. 1982. Dynamics of the Holocene landscape zones in the European north-east of the USSR // Razvitiye prirody territorii SSSR v pozdnem Pleistocene i Holocene / Velichko A.A (ed.). Moscow: Nauka. P.154 -162. (in Russian).

Novikov S.M., Usova L.I., Malyasova E.S. 1999. Age and dynamics of bogs of West Siberia // Bolota i zabolochennie lesa v svete zadach ustoichivogo prirodopolzovaniya. Materialy konferentsii / Vompersky S.A. and Sirin A.A (eds.) Moscow: GEOS. P 72-76. (in Russian).

Paleopalynology. 1966. T. 1. Leningrad: Nedra. 352 pp. (in Russian).

Panova N.K., Jankovska V., Korona O.M., Zinov'ev E.V. 2003. The Holocene dynamics of vegetation and ecological conditions of the Polar Urals // Russian Journal of Ecology. No 4. P. 248-260.

Panova N.K., Makovsky V.I., Khizhnyak V.A. 2001. Results of studies on bogs and Holocene forest vegetation development in the Visim reserve // Issledovaniya etalonnikh prirodnykh kompleksov Urala. Materialy konferentsii k 30-letiyu Visimskogo zapovednika. Ekaterinburg. P.349-365. (in Russian).

Shiyatov S.G. 1986. Dendrochronology of the Upper Tree-Limit in the Ural Mts. Moscow: Nauka. 136 pp. (in Russian).

Shiyatov S.G. 2003. Rates of Change in the Upper Treeline Ecotone in the Polar Ural Mountains // Pages News. Past Global Changes. V. 11. No 1. P. 8 -10.

Shiyatov S.G., Mazepa V.S. 2002. Climate-caused dynamics of forest-tundra ecosystems in the mountains of the Polar Urals // Ecological problems of mountian territories. Reports of international scientific conference / Vasil'ev A.G. (ed.). Ekaterinburg: Academkniga. P. 41- 45. (in Russian).

Shvareva Yu.N. 1962. Climate of the Pre-Polar and Polar Urals // Issledovaniya lednikov i lednikovykh ra' yonov / Avsyuk G.A. (ed). Moscow: AN SSSR. P.176 -199. (in Russian).

Sukhachev V.N. 1922. To the problem of changes of climate and vegetation in the Siberia north after the Tertiary time // Meteorologhichesky Vestnik. T. 32. No. 1-4. P. 25-43. (in Russian).

Surova T.G. 1967. About vegetation development of Polar Urals during the Holocene // Vestnik Moskovskogo Universiteta. No 2. P. 66-68. (in Russian).

Surova T.G., Troitsky L.S. 1971. Dynamics of vegetation, climate and glaciation in the Polar Ural Mts. during the Holocene according to palynological study // Palinologiya golocena / Neistadt M.I. (ed.). Moscow: Nauka. P. 121-135. (in Russian).

Surova T.G., Troitsky L.S., Punning J.-M. 1975: Holocene paleography and absolute chronology of the Polar Ural Mts. // Izvestiya Academii nauk Estonskoy SSR. T. 24. Khimia. Geoloogia. P.152-159. (in Russian).

Vaganov E.A., Shiyatov S.G., Mazepa V.S. 1996. Dendroclimatic studies in the Ural and Siberian Subarctic. Novosibirsk: Nauka. 245 pp. (in Russian).

Vaganov E.A., Shiyatov S.G., Khantemirov R.M., Naurzbaeva M.M. 1998. Variation of air summer temperatures in high latitudes of North Hemisphere during the last 1500 years: comparative analyses of tree-ring data and ice cores analyses // Doklady Akademii Nauk. T. 358. No 5. P. 681-684. (in Russian).

Velichko A.A. 1989. Relationship of climate changes in high and low latitudes of the Earth in the Late Pleistocene and Holocene //

Paleoklimaty i oledeneniya v Pleistocene / Velichko A.A. (ed.). Moscow: Nauka. P. 5-19. (in Russian).

Velichko A.A. 1991. Global changes of climate and reaction of landscape cover // Izvestiya AN SSSR. Geographical series. No 5. P. 5-22. (in Russian).

Velichko A.A., Klimanov V.A. 1990. Climatic conditions in the Northern Hemisphere 5000-6000 years ago // Izvestiya AN SSSR. Geographical series. No 5. P. 38-51. (in Russian). 


\title{
ИСТОРИЯ ПРИРОДНОЙ СРЕДЫ И РАЗВИТИЯ БОЛОТ В ГОЛОЦЕНЕ НА ВОСТОЧНОМ СКЛОНЕ ПОЛЯРНОГО И ПРИПОЛЯРНОГО УРАЛА, РОССИЯ
}

\author{
Панова Н.К. ${ }^{l}$, Антипина Т.Г., Янковска В. ${ }^{2}$ \\ ${ }^{1}$ Ботанический сад Уральского отделения Российской академии наук, г. Екатеринбург \\ ${ }^{2}$ Институт ботаники Академии наук Чешской республики, г. Брно
}

Исследовались отложения мерзлых торфяников, вскрытых естественными обнажениями в берегах озер, ручьев и рек в зоне лесотундры восточного склона Полярного и северной тайги - Приполярного Урала методами палинологического, ботанического и радиоуглеродного анализов. В результате установлены основные этапьи динамики растительности, экологических условий и прочесса торфообразования в голочене от предбореального до субатлантического периодов.

В предбореальном периоде (более 9 тысяч лет назад) преобладала травяно-кустарниковая растительность: карликовые березки, ивы, злаки, осоки, польни, маревые, разнотравье, споровые растения (мхи, хвощи) в сочетании с редколесьями из березы и лиственницы, а на Приполярном Урале - с примесью ели. Климатические условия были холодными и относительно сухими.

C потеплением в бореальном периоде (около 9 тысяч лет назад) началась деградация многолетней мерзлоты, образование застойного переувлажнения пониженных участков, последующее зарастание их водными и водно-болотными растениями (рогоз, частуха, вахта, осоки и др.) и начало прочесса торфообразования. На суходолах сформировались редкостойные леса паркового типа: лиственнично-березовые на Полярном Урале и лиственнично-еловые - на Приполярном.

Атлантический период (8-5 тысяч лет назад) отличался наиболее теплыми климатическими условиями, оптимальными для произрастания мезофильной флоры и интенсивного торфонакопления. В это время ель распространилась на Полярный Урал, образовав там таежные еловые леса с примесью березы и лиственницы. На Приполярном Урале в это время произрастали хвойные леса также с преобладанием ели, с участием сосны, сибирского кедра и пихты средне- и южно-таежного облика.

Похолодание в суббореальном периоде (около 3400 лет назад) привело к изреживанию древостоев, отступлению ели, прекращению торфообразования и последующему промерзанию торфяников. На Полярном Урале таежные леса сменились лесотундрой, на Приполярном Урале сформировались елово-сосново-кедровые леса северо-таежного типа.

Установленная динамика растительности и болотообразовательного процесса на Приполярном Урале и Полярном Урале имеет идентичную направленность и отражает влияние общеклиматических изменений. Отличие заключается в более раннем начале торфонакопления и распространения ели на Приполярном Урале, где с атлантического периода произрастали также сосна и сибирский кедр. До Полярного Урала эти виды, по нашим данным, не доходили. Эти особенности несомненно обусловлены разницей в широтно-географическом расположении районов исследования и направлением распространения древесных растений в голоцене с юга на север вдоль восточного склона Уральских гор и вглубь хребта по долинам рек и вверх по горным склонам.

Ключевые слова: голоцен, торфяные болота, пыльца, споры, растительность, изменения климата.

Поступила в редакцию: 14.12.2010 Переработанный вариант: 18.12.2010 